\title{
DIALEKTIKA PUHLIK
}

$\perp \quad \operatorname{ISSN}($ Print) 2528-3332 $\mid$ ISSN (Online) 2621-2218

Jurnal dapat diakses di http:// ejournal.upbatam.ac.id/index.php/dialektikapublik

\section{Implementasi Program Keluarga Harapan (PKH) Dalam Rangka Pemerataan Kesejahteraan Masyarakat di Kabupaten Bungo}

\author{
Deni Handani ${ }^{1}$, Mela Sari², Ira Devi Lia ${ }^{3}$ \\ ${ }^{I}$ Sekolah Tinggi Ilmu Administrasi Setih Setio Muara Bungo \\ ${ }^{2}$ Sekolah Tinggi Ilmu Administrasi Setih Setio Muara Bungo \\ ${ }_{3}^{3}$ Sekolah Tinggi Ilmu Administrasi Setih Setio Muara Bungo
}

\section{INFORMASI ARTIKEL}

\section{Sejarah Artikel:}

Diterima Redaksi: 25 Juli 2019

Revisi Akhir: 15 Agustus 2019

Diterbitkan Online: 30 Agustus 2019

\begin{tabular}{l} 
KATA KUNCI \\
\hline Implementasi, Program Keluarga Harapan (PKH), \\
Kesejahteraan Masyarakat \\
KORESPONDENSI \\
\hline
\end{tabular}

No HP: 082372763899

E-mail: melazuhel@gmail.com

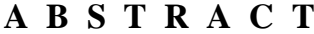

\begin{abstract}
Policy of Assistance to the Family Hope Program (PKH) through Law Number 40 of 2004 concerning the National Social Security System which was followed up with Regulation of the Minister of Social Affairs of the Republic of Indonesia Number 1 of 2018 concerning PKH. One way that has been done by the government to prosper and reduce poverty by giving assistance to shortage society. The aim of this study was to identify the Implementation of the Family Hope Program in the framework of the distribution of community welfare in Bungo District. The study used descriptive method with qualitative. Data analysis using data collection, data reduction, presentation and drawing conclusions and verification. The results showed that the implementation of the policies carried out by related government agencies was improving the quality of life in the fields of education and health, but the reality in the field was found that the implementation of the family of hope program in Bungo district had not been able to fully realize equitable welfare for the community, this was indicated from the distribution of funds that had not been equitable and injustice in determining the participants receiving $P K H$ funds.
\end{abstract}

\section{PENDAHULUAN}

Pemerintahan telah menetapkan kebijakan tentang sistem perlindungan sosial di Indonesia melalui Undang-Undang Nomor 11 Tahun 2009 Tentang Kesejahteraan Sosial yang tercantum pada pasal 1 Ayat 9 Perlindungan Sosial adalah semua upaya yang diarahkan untuk mencegah dan menangani dari guncangan dan kerentanan sosial. Salah satu cara yang telah dilakukan oleh pemerintah untuk mensejahterakan dan mengurangi kemiskinan adalah dengan memberikan bantuan kepada masyarakat yang kurang mampu. Bantuan-bantuan itu diberikan dalam bentuk tunai maupun non tunai (Sri Masita Laluhang).

Pemerintah menetapkan kebijakan Bantuan Program Keluarga Harapan (PKH) melalui Undang-undang Nomor 1 Tahun 2018 Tentang Program Keluarga Harapan. Program Keluarga Harapan atau yang biasa disebut sebagai PKH adalah program pemberian bantuan sosial bersyarat kepada Keluarga Penerima Manfaat (KPM) yang ditetapkan sebagai keluarga penerima manfaat Program Keluarga Harapan. PKH terfokus pada dua komponen sebagai peningkatan kualitas sumber daya manusia yaitu pada bidang kesehatan dan pendidikan. Sasaran Peserta PKH adalah Keluarga Miskin (KM), dan yang memiliki komponen kesehatan (Ibu Hamil, nifas, balita, anak prasekolah) dan komponen pendidikan (SD sederajat, SMP sederajat, SMA sederajat) atau anak usia
6-21 tahun yang belum menyelesaikan pendidikan wajib 12 (dua belas) tahun, penyandang disabilitas berat, dan lanjut usia diatas 70 (tujuh puluh) tahun.

Sistem penyaluran dana bantuan PKH ini sebelumnya masih menggunakan cara tunai dan bagi penerima bantuan harus mengambil uangnya dikantor Pos, tetapi sejak tahun 2016 Bantuan Program Keluarga Harapan ini penerimanya dimudahkan dengan sistem perbankan, penerima bantuan bisa mengambil uang secara non tunai melalui Bank BRI atau Cabang ATM BRI terdekat.

Tabel 1

Nominal Bantuan Program Keluarga Harapan

\begin{tabular}{|c|c|c|c|c|c|}
\hline \multirow{2}{*}{$\begin{array}{c}\text { Kompon } \\
\text { en }\end{array}$} & \multicolumn{4}{|c|}{ Tahap/Triwulan } & \multirow{2}{*}{$\begin{array}{l}\text { Total/ } \\
\text { Tahun }\end{array}$} \\
\hline & $\mathbf{I}$ & II & III & IV & \\
\hline $\begin{array}{c}\text { Kesehata } \\
n+ \\
\text { Pendidik } \\
\text { an }\end{array}$ & $\begin{array}{c}\text { Rp. } \\
500.000\end{array}$ & $\begin{array}{c}\text { Rp. } \\
500.000\end{array}$ & $\begin{array}{c}\text { Rp. } \\
500.000\end{array}$ & $\begin{array}{c}\text { Rp. } \\
390.000\end{array}$ & $\begin{array}{c}\text { Rp. } \\
1.830 .000\end{array}$ \\
\hline $\begin{array}{c}\text { Kesos } \\
\text { (Lanjut } \\
\text { Usia + }\end{array}$ & $\begin{array}{c}\text { Rp. } \\
500.000\end{array}$ & $\begin{array}{c}\text { Rp. } \\
500.000\end{array}$ & $\begin{array}{c}\text { Rp. } \\
500.000\end{array}$ & $\begin{array}{c}\text { Rp. } \\
500.000\end{array}$ & $\begin{array}{c}\text { Rp. } \\
2.000 .000\end{array}$ \\
\hline
\end{tabular}




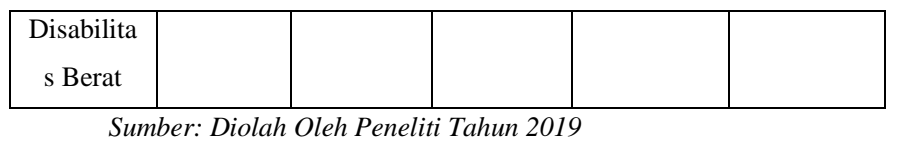

Dari tabel 1 diatas dapat dilihat besar bantuan dana PKH tiap tahapan yang diterima oleh penerima bantuan adalah setiap tiga bulan sekali atau yang biasa disebut dengan pertriwulan. Total bantuan dana untuk komponen kesehatan dan pendidikan sebesar Rp. 1.830.000,/tahun sedangkan bagi lanjut usia dan penyandang disabilitas menerima bantuan sebesar Rp. 2.000.000,-/tahun.

PKH telah diterapkan ke Daerah-daerah yang telah memenuhi syarat yang ditentukan, Salah satunya adalah di Kabupaten Bungo. Di Kabupaten Bungo instansi yang melaksanakan PKH adalah Kantor Dinas Sosial, Pengendalian Penduduk, Keluarga Berencana, Pemberdayaan Perempuan dan Perlindungan Anak Kabupaten Bungo yang selanjutnya di singkat Dinas Sosial, PPKB dan P3A yang beralamat di Jalan Diponegoro Nomor 10, Rimbo Tengah Kabupaten Bungo, Provinsi Jambi. Di kabupaten Bungo penerima PKH tersebar di 17 Kecamatan, dapat dilihat pada table 2 berikut:

Tabel 2

Rekapitulasi Alokasi Data Penerima PKH di Kabupaten Bungo Tahun 2014 - 2017 (KK)

\begin{tabular}{|c|c|c|c|c|c|}
\hline \multirow[t]{2}{*}{ No } & \multirow[t]{2}{*}{ Kecamatan } & \multicolumn{4}{|c|}{ Jumlah/Tahun } \\
\hline & & 2014 & 2015 & 2016 & 2017 \\
\hline 1 & $\begin{array}{ll}\text { Bathin } & \text { II } \\
\text { Babeko } & \end{array}$ & 0 & 0 & 0 & 0 \\
\hline 2 & $\begin{array}{ll}\text { Bathin } & \text { II } \\
\text { Pelayang }\end{array}$ & 0 & 95 & 202 & 204 \\
\hline 3 & Bathin III & 0 & 162 & 218 & 216 \\
\hline 4 & Bathin III Ulu & 182 & 181 & 276 & 275 \\
\hline 5 & Bungo Dani & 0 & 84 & 215 & 218 \\
\hline 6 & Jujuhan & 0 & 142 & 206 & 195 \\
\hline 7 & Jujuhan Ilir & 0 & 0 & 170 & 170 \\
\hline 8 & $\begin{array}{l}\text { Limbur Lubuk } \\
\text { Mengkuang }\end{array}$ & 0 & 82 & 183 & 180 \\
\hline 9 & $\begin{array}{l}\text { Muko-Muko } \\
\text { Bathin VII }\end{array}$ & 127 & 122 & 399 & 402 \\
\hline 10 & \begin{tabular}{|ll} 
Pasar & Muara \\
Bungo & \\
\end{tabular} & 0 & 101 & 218 & 216 \\
\hline 11 & Pelepat & 182 & 178 & 432 & 431 \\
\hline 12 & Pelepat Ilir & 0 & 142 & 277 & 267 \\
\hline 13 & Rantau Pandan & 0 & 187 & 247 & 244 \\
\hline 14 & Rimbo Tengah & 0 & 92 & 186 & 181 \\
\hline 15 & $\begin{array}{l}\text { Tanah } \\
\text { Sepenggal }\end{array}$ & 205 & 205 & 301 & 301 \\
\hline 16 & $\begin{array}{l}\text { Tanah } \\
\text { Sepenggal } \\
\text { Lintas }\end{array}$ & 235 & 231 & 334 & 327 \\
\hline 17 & Tanah Tumbuh & 0 & 121 & 233 & 230 \\
\hline & Jumlah & 931 & 2.125 & $\begin{array}{c}4.09 \\
7\end{array}$ & 4.075 \\
\hline
\end{tabular}

58 Deni Handani
Sumber: Dinas Sosial, PPKB dan P3A Tahun 2019

Berdasarkan tabel 2 diatas tentang rekapitulasi alokasi data penerima PKH Kabupaten Bungo, dapat dilihat bahwa dari 17 Kecamatan yang ada di Kabupaten Bungo, Kecamatan Bathin II Babeko sejak tahun 2014-2017 belum mendapatkan dana bantuan PKH dikarenakan pemberian dana $\mathrm{PKH}$ diberikan secara bertahap disetiap kecamatan. Kecamatan Bathin II Babeko baru mulai mendapatkan dana bantuan PKH di tahun 2018.

Bantuan Program Keluarga Harapan ini mempunyai pendamping $\mathrm{PKH}$, pendamping $\mathrm{PKH}$ berperan untuk mendampingi peserta PKH menerima bantuan tanpa ada potongan dari siapapun. Tugas utama pendamping PKH adalah melaksanakan seluruh tahapan pelaksanaan PKH yakni pertemuan awal, Validasi KM, pemutakhiran data, verifikasi komitmen kehadiran dilayanan pendidikan dan kesehatan, mengawal penyaluran bantuan, melakukan pertemuan peningkatan kemampuan keluarga (P2K2), melakukan penanganan pengaduan, membuat laporan serta menyelesaikan permasalahan yang timbul dalam pelaksanaan PKH di lapangan.

Berdasarkan observasi awal penelitian, ditemukan beberapa fenomena/masalah diantaranya : Sosialisasi tentang $\mathrm{PKH}$ dan Penggunaan dana PKH pada penerima belum sepenuhnya dilakukan oleh Unit Pelaksana Program Keluarga Harapan (UPPKH); Pertemuan rutin kelompok belum sepenuhnya berjalan dengan baik. Berdasarkan uraian di atas, peneliti tertarik untuk melakukan penelitian ilmiah dengan judul: Implementasi Program Keluarga Harapan (PKH) Dalam Rangka Pemerataan Kesejahteraan Masyarakat di Kabupaten Bungo.

Berdasarkan batasan masalah diatas yang menjadi rumusan masalah dalam penelitian ini adalah Bagaimana Implementasi Program Keluarga Harapan (PKH) dalam rangka pemerataan kesejahteraan masyarakat di Kabupaten Bungo ?

Adapun tujuan dari penelitian ini yaitu untuk mengidentifikasi Implementasi Program Keluarga Harapan (PKH) dalam rangka pemerataan kesejahteraan masyarakat di Kabupaten Bungo.

\section{TINJAUAN PUSTAKA}

\section{Konsep Implementasi}

Van Meter dan Van Horn (Zulkarnain Umar) mengungkapkan Those action by public and private individual (or groups) that are the achievement or objectives set forth in prior policy (bahwa implementasi mengandung pengertian tindakan yang dilakukakan oleh individu atau pejabat maupun swasta yang mengarah pada tujuan yang ditetapkan). Tindakan-tindakan tersebut adalah berupa upaya-upaya untuk mengadministrasikan dan menimbulkan dampak nyata pada masyarakat. Model yang diperkenalkan oleh duet Donald Van Metter dengan Carl Van Horn yang berkaitan dengan Kebijakan publik yakni model yang mengandaikan bahwa implementasi kebijakan berjalan secara linier dari Kebijakan Publik, implementor dan kinerja kebijakan publik (Budi Winarno : 2008:155). 
Model implementasi kebijakan Van Meter dan Van Horn (Riant Nugroho, 2003:165) mengandaikan bahwa implementasi kebijakan berjalan secara linier dari kebijakan publik, implementor dan kinerja kebijakan publik. Beberapa variabel yang mempengaruhi kebijakan publik adalah variabel :

1) Ukuran (Standar) dan Tujuan Kebijakan

Kinerja implementasi kebijakan dapat diukur tingkat keberhasilannya jika dan hanya jika ukuran dan tujuan dari kebijakan memang realistis dengan sosio-kultur yang ada dilevel pelaksana kebijakan. Ketika ukuran kebijakan atau tujuan kebijakan terlalu ideal (bahkan terlalu utopis) untuk dilaksanakan dilevel warga, maka agak sulit merealisasikan kebijakan publik hingga titik yang dapat dikatakan berhasil.

2) Sumberdaya

Keberhasilan proses implementasi kebijakan sangat tergantung dari kemampuan memanfaatkan sumber daya yang tersedia. Manusia merupakan sumber daya yang terpenting dalam menentukan suatu keberhasilan proses implementasi. Tahaptahap tertentu dari keseluruhan proses implementasi menurut adanya sumber daya manusia yang berkualitas sesuai dengan pekerjaan yang diisyaratkan oleh kebijakan yang telah ditetapkan secara politik. Tetapi ketika kompetisi dan kapabilitas dari sumber-sumber daya itu nihil, maka sangat sulit untuk diharapkan.

3) Karakteristik agen pelaksana

Pusat perhatian pada agen pelaksana meliputi organisasi formal dan organisasi non formal yang akan terlibat pengimplementasian kebijakan publik. Hal ini sangat penting karena kinerja implementasi kebijakan publik akan sangat banyak dipengaruhi oleh ciri-ciri yang tepat serta cocok dengan para agen pelaksananya. Misalnya implementasi kebijakan publik yang berusaha untuk merubah perilaku atau tingkah laku manusia secara radikal, maka agen pelaksana proyek itu haruslah berkarakterisktik keras dan ketat pada aturan serta sanksi hukum. Sedangkan bila kebijakan publik itu tidak terlalu merubah perilaku dasar manusia maka dapat saja agen pelaksana yang diturunkan tidak setegas pada gambaran yang pertama. Selain itu cakupan atau luas wilayah implementasi kebijakan perlu juga diperhitungkan manakala hendak menentukan agen pelaksana. Maka seharusnya semakin besar pula agen yang dilibatkan.

4) Komunikasi antar organisasi aktivitas pelaksana

Koordinasi merupakan mekanisme yang ampuh dalam implementasi kebijakan publik. Semakin baik komunikasi dan koordinasi diantara pihak-pihak yang terlibat dalam suatu proses implementasi, maka asumsinya kesalahan-kesalahan akan sangat kecil untuk terjadi, dan begitu pula sebaliknya.

5) Lingkungan ekonomi, sosial, dan politik

Hal lain yang perlu diperhatikan guna menilai kinerja implementasi kebijakan publik dalam perspektif yang ditawarkan oleh Van Meter dan Van Horn adalah sejauhmana lingkungan eksternal turut mendorong keberhasilan kebijakan publik yang telah ditetapkan. Lingkungan sosial, ekonomi dan politik yang tidak kondusif dapat menjadi penyebab dari kegagalan kinerja implementasi kebijakan. Olehnya itu, upaya untuk mengimplementasikan kebijakan harus pula memperhatikan kekondusifan lingkungan eksternal. Van Meter dan Van Horn juga mengajukan hipotesis bahwa lingkungan ekonomi, sosial, dan politik dari yuridiksi atau organisasi pelaksana akan mempengaruhi karakter badan-badan pelaksana, kecenderungan-kecenderungan para pelaksana dan pencapaian itu sendiri.

6) Kecenderungan (disposition) dari pelaksana/implementor

Sikap penerimaan atau penolakan dari agen pelaksana akan sangat banyak mempengaruhi keberhasilan atau tidaknya kinerja implementasi kebijakan publik. Hal ini sangat mungkin terjadi oleh karena kebijakan yang dilaksanakan bukanlah hasil formulasi warga setempat yang mengenal betul persoalan dan permasalahan yang mereka rasakan. Melainkan kebijakan yang akan implementor laksanakan adalah kebijakan "dari atas ke bawah" (top down) yang sangat mungkin para pengambil keputusannya tidak mengetahui (bahkan tidak mampu menyentuh) kebutuhan, keinginan, atau permasalahan yang warga ingin selesaikan.

\section{Tujuan Program Keluarga Harapan}

Tujuan utama dari PKH adalah untuk mengurangi kemiskinan dan meningkatkan kualitas sumber daya manusia. Terutama pada kelompok masyarakat miskin. Tujuan tersebut sekaligus sebagai upaya mempercepat pencapaian target. Dalam pelaksanaannya PKH memiliki tujuan umum dan tujuan khusus. Adapun tujuan adalah untuk mengurangi angka dan memutus rantai kemiskinan, meningkatkan kualitas sumber daya manusia, serta merubah perilaku RTSM yang relatif kurang peningkatan kesejahteraan.

Adapun secara khusus, tujuan dari PKH dalam Pedoman umum PKH tahun 2008 halaman 12 terdiri atas:

1) Meningkatkan kondisi sosial ekonomi RTSM.

2) Meningkatkan taraf pendidikan anak-anak RTSM.

3) Meningkatkan status kesehatan dan gizi ibu hamil, ibu nifas, dan anak dibawah 6 tahun dari RTSM.

4) Meningkatkan akses dan kualitas pelayanan pendidikan dan kesehatan, khususnya bagi RTSM.

Sasaran atau Penerima bantuan PKH (Dedy,dkk) adalah Rumah Tangga Sangat Miskin (RTSM) yang memiliki anggota keluarga yang terdiri dari anak usia 0-15 tahun dan/atau ibu hamil/nifas dan berada pada lokasi terpilih. Penerima bantuan adalah ibu atau wanita dewasa yang mengurus anak pada rumah tangga yang bersangkutan hal ini dikarenakan agar pemenuhan syarat ini dapat berjalan secara efektif.

\section{Konsep Kesejahteraan Sosial}

James Midgley (Isbandi, 2013:23) mendefenisikan Kesejahteraan Sosial sebagai suatu kondisi dalam suatu masyarakat. Midgley melihat Kesejahteraan Sosial sebagai : “ a state or condition of human well-being that exists when social problems are managed, when human social opportunities are maximized" (suatu keadaan atau kondisi Implementasi Program Keluarga 59 
kehidupan manusia yang tercipta ketika berbagai permasalahan sosial dapat dikelola dengan baik, ketika kebutuhan manusia dapat terpenuhi dan ketika kesempatan sosial dapat dimaksimalisasikan). Sedangkan di Indonesia, pengertian Kesejahteraan Sosial tidak dapat dilepaskan dari apa yang telah dirumuskan dalam Undang-undang Nomor 11 Tahun 2009 tentang Kesejahteraan Sosial, Pasal 1 ayat 1: "Kesejahteraan Sosial ialah kondisi terpenuhinya kebutuhan material, spiritual, dan sosial warga Negara agar dapat melaksanakan fungsi sosialnya.

Rumusan diatas menggambarkan Kesejahteraan Sosial sebagai suatu keadaan dimana digambarkan secara ideal adalah suatu tatanan (tata kehidupan) yang meliputi kehidupan material maupun spiritual, dengan tidak menempatkan satu aspek lebih penting dari yang lainnya, tetapi lebih mencoba melihat pada upaya mendapatkan titik keseimbangan antara aspek sosial, material, dan spiritual.

Keluarga sejahtera adalah keluarga yang dibentuk atas perkawinan yang sah, mampu memenuhi kebutuhan hidup spiritual dan materil yang layak, bertaqwa kepada Tuhan Yang Maha Esa, memiliki hubungan yang yang serasi, selaras dan seimbang antar anggota dan antar keluarga dengan masyarakat dan lingkungan (Undang-Undang Republik Indonesia Nomor 52 tahun 2009). untuk mendapatkan gambaran yang lebih jelas tentang tingkat kesejahteraan akan digunakan beberapa indikator yang telah digunakan oleh BKKBN (Badan Koordinator Keluarga Berencana Nasional). Adapun beberapa indikator tersebut adalah sebagai berikut :

1) Keluarga Pra Sejahtera : Keluarga yang tidak dapat memenuhi syarat-syarat sebagai keluarga sejahtera I atau indikator dasar keluarga.

2) Keluarga Sejahtera I : Yaitu keluarga mampu memenuhi 6 (enam) indikator tahapan Keluarga Sejahtera I, tetapi tidak memenuhi salah satu dari 8 (delapan) indikator keluarga sejahtera II atau indikator kebutuhan psikologis keluarga:

a. Pada umumnya anggota keluarga makan dua kali sehari atau lebih.

b. Anggota keluarga memiliki pakaian yang berbeda untuk dirumah, bekerja atau sekolah dan berpergian.

c. Rumah yang ditempati keluarga mempunyai atap, lantai dan dinding yang baik.

d. Bila ada anggota keluarga sakit dibawa kesarana kesehatan.

e. Bila pasangan usia subur ingin ber KB pergi kesarana pelayanan kontrasepsi.

f. Semua anak umur 7-15 tahun dalam keluarga bersekolah.

3) Keluarga Sejahtera II : Yaitu keluarga yang mampu memenuhi 6 (enam) indikator tahapan keluarga sejahtera I dan 8 (delapan) indikator keluarga sejahtera II, tetapi tidak memenuhi salah satu dari 5 (lima) indikator keluarga sejahtera III atau indikator kebutuhan pengembangan dari keluarga:

a. Anggota keluarga melaksanakan ibadah secara teratur menurut agama yang dianut masing-masing. b. Minimal seminggu sekali keluarga tersebut menyediakan daging, ikan, telur sebagai lauk pauk.

c. Memperoleh pakaian baru dalam setahun terakhir.

d. Luas lantai tiap penghuni rumah satu $8 \mathrm{~m}^{2}$.

e. Anggota keluarga sehat dalam keadaan tiga bulan terakhir, sehingga dapat menjalankan fungsi masingmasing.

f. Ada seorang atau lebih anggota keluarga yang bekerja untuk memperoleh penghasilan.

g. Bisa baca tulis latin bagi anggota keluarga dewasa yang berumur 10-60 tahun.

h. Anak hidup dua atau lebih dan saat ini masih memakai alat kontrasepsi.

4) Keluarga Sejahtera III : Yaitu keluarga yang mampu memenuhi 6 (enam) indikator tahapan keluarga sejahtera I, 8 (delapan) indikator keluarga sejahtera II dan 5 (lima) indikator keluarga sejahtera III, tetapi tidak memenuhi salah satu dari 2 (dua) indikator keluarga sejahtera III plus atau indikator aktualisasi diri keluarga.

a. Keluarga mempunyai upaya untuk meningkatkan pengetahuan agama.

b. Sebagian penghasilan keluarga ditabung dalam bentuk uang atau barang.

c. Kebiasaan keluarga makan bersama paling kurang seminggu sekali dimanfaatkan untuk berkomunikasi.

d. Turut serta dalam kegiatan masyarakat dilingkungan tempat tinggal.

e. Keluarga mengadakan rekreasi bersama minimal sekali dalam 6 bulan.

f. Keluarga dapat memperoleh berita dari surat kabar, radio, televisi dan majalah.

5) Keluarga Sejahtera III Plus : Yaitu keluarga yang mampu memenuhi keseluruhan dari 6 (enam) indikator tahapan keluarga sejahtera I, 8 (delapan) indikator keluarga sejahtera II, 5 (lima) indikator keluarga sejahtera III, serta 2 (dua) indikator tahapan tahapan keluarga sejahtera III plus.

a. Memberikan sumbangan secara teratur dan sukarela untuk kegiatan sosial masyarakat dalam bentuk materi.

b. Ada anggota keluarga yang aktif sebagai pengurus perkumpulan sosial, yayasan atau instusi masyarakat.

\section{METODOLOGI}

Adapun metode yang dipilih dalam penelitian ini adalah metode kualitatif deskriptif atau memaparkan secara keseluruhan (comprehensive) aspek-aspek yang ada. Metode penelitian kualitatif deskriptif adalah metode yang digunakan untuk menemukan pengetahuan terhadap subjek penelitian pada suatu saat tertentu. Kata deskriptif berasal dari bahasa latin “descriptivus"yang berarti uraian. Penelitian deskriptif merupakan penelitian yang dimaksudkan untuk mengumpulkan informasi mengenai subyek penelitian dan perilaku subyek penelitian pada suatu periode tertentu. Penelitian deskriptif kualitatif berusaha mendeskripsikan seluruh gejala atau keadaan yang 
ada, yaitu keadaan gejala menurut apa adanya saat penelitian dilakukan (Mukhtar : 2013)

\section{HASIL DAN PEMBAHASAN}

Dalam pembahasan tentang implementasi Program Keluarga Harapan ini peneliti menggunakan model implementasi kebijakan Van Meter dan Van Horn, sebagai berikut:

\section{Ukuran (Standar) dan Tujuan Kebijakan}

Pemerintah telah melaksanakan PKH sejak tahun 2007. Tujuan kebijakan ini dibentuk adalah untuk memberi perlindungan sosial bagi keluarga miskin melalui akses layanan pendidikan, kesehatan dan kesejahteraan sosial sebagai upaya untuk penanggulangan kemiskinan melalui pemberian bantuan dana tunai bersyarat, dalam jangka pendek PKH diharapkan mampu membantu keluarga miskin mengurangi beban pengeluaran.

Bantuan PKH ini ditujukan kepada dua bidang yaitu bidang pendidikan dan kesehatan. Dikabupaten Bungo, Program Keluarga Harapan dimulai pada tahun 2014 dengan jumlah penerima 931 jiwa hingga 2017 telah mencapai 4.075 jiwa, Pemerintah menerapakan kebijakan bantuan PKH melalui Undang-Undang Nomor 40 Tahun 2004 tentang Sistem Jaminan Sosial Nasional yang ditindak lanjuti dengan Peraturan Menteri Sosial Republik Indonesia Nomor 1 tahun 2018 tentang Program Keluarga Harapan. Sasara atau penerima PKH di Kabupaten Bungo adalah rumah tangga yang dikatakan rentan miskin. Jika dilihat dari pelaksanaan tujuan program PKH di kabupaten Bungo belum $100 \%$ berhasil karena belum sepenuhnya bisa mencukupi kebutuhan pendidikan dan kesehatan masyarakat, hal ini ditunjukkan dari belum semua masyarakat miskin di Bungo dapat di rangkul oleh PKH dan ini juga dibuktikan oleh fakta yang ada dilapangan bahwa masih banyak ketidakseimbangan dalam pemberian dana $\mathrm{PKH}$.

\section{Sumber Daya}

Sumber daya yang dalam hal ini ialah Implementor diketahui bahwa pelaksana Program Keluarga Harapan pada Dinas Sosial Pengendalian Penduduk dan Keluarga Berencana, Pemberdayaan Perempuan dan Perlindungan Anak Kabupaten Bungo berjumlah 42 orang yang terdiri dari 1 (satu) Koordinator Kabupaten, 2 (dua) orang operator $\mathrm{PKH}$ dan 39 (tiga puluh sembilan) orang pendamping $\mathrm{PKH}$ dengan struktur sebagai berikut : (1) Pengarah : Kepala Dinas Sosial; (2) Ketua : Kepala Bidang Perlindungan/Jaminan Sosial; (3) Sekretaris : Kepala Seksi Bidang Sosial; (4) Koordinator Kabupaten/kota; (5) Pendamping/Operator.

Sumberdaya pada Dinas Sosial, Pengendalian Penduduk dan Keluarga Berencana, Pemberdayaan Perempuan dan Perlindungan Anak Kabupaten Bungo salah satunya ada pendamping PKH. Pendamping mempunyai tugas pokok dan fungsi untuk memantau, mengelola, menginformasikan dan menyelesaikan permasalahan penyaluran bantuan kepada instansi atau pihak terkait sesuai dengan derajat permasalahannya. Untuk di Kabupaten Bungo semua pendamping sudah melakukan tugas nya dengan baik, belum ada yang di tegur karena tidak bekerja dengan benar. Untuk sanksi yang diberikan kepada pendamping jika tidak menjalankan tugas pokok dan fungsi nya dengan baik akan diberikan teguran lisan terlebih dahulu dan jika masih berlanjut akan Deni Handani ditindak lanjuti dengan pemberian surat peringatan 1 , 2, dan 3 hingga pemberhentian dari pendamping PKH. Maka dapat disimpulkan bawah untuk sumberdaya dalam pelaksanaan program PKH ini sudah cukup baik dari segi kuantitas maupun kualitas.

\section{Karakteristik Agen Pelaksana}

Van Meter dan Van Horn mengungkapkan pusat perhatian pada agen pelaksana meliputi organisasi yang akan terlibat pengimplementasian kebijakan publik. Misalnya implementasi kebijakan publik yang berusaha untuk merubah perilaku atau tingkah laku manusia secara radikal, maka agen pelaksana itu haruslah berkarakteristik keras dan ketat pada aturan serta sanksi hukum. Bantuan PKH ini di tujukan kepada dua bidang yaitu bidang pendidikan dan kesehatan. Pada program ini Dinas Sosial P2KB dan P3A harus bersikap keras dan ketat terhadap aturan dan sanksi hukum kepada peserta PKH yang tidak memenuhi komitmen pada fasilitas layanan kesehatan, pendidikan dan kesejahteraan sosial. Peserta $\mathrm{PKH}$ ini harus terdaftar dan hadir pada fasilitas kesehatan dan pendidikan terdekat.

Pendamping $\mathrm{PKH}$ berkewajiban mengecek, memantau para peserta PKH. Peserta $\mathrm{PKH}$ pun harus menggunakan dana bantuan dengan seharusnya di bidang pendidikan dan kesehatan. Jika terdapat penerima yang tidak menggunakan dana bantuan dengan seharusnya uang bantuan akan di tangguhkan dan bisa sampai dikeluarkan dari kepesertaan PKH. Tetapi pada fakta dilapangan pendamping belum sepenuhnya memberikan ketegasan kepada penerima seperti sanksi yang berlaku, pendamping hanya memberikan teguran kepada penerima yang tidak memenuhi komitmennya.

\section{Komunikasi Antar Organisasi Aktivitas Pelaksana}

Koordinasi merupakan mekanisme yang ampuh dalam implementasi kebijakan publik. Semakin baik komunikasi dan koordinasi diantara pihak-pihak yang terlibat dalam suatu proses implementasi, maka asumsinya kesalahan-kesalahan akan sangat kecil untuk terjadi. Dan begitu pula sebaiknya.

Program ini dalam pelaksanaannya bekerjasama dengan Kementerian atau Lembaga baik ditingkat pusat maupun daerah sebagai mitra kerja salah satunya yang berkoordinasi dengan Badan Pusat Statistik (BPS), yang berperan dalam pelaksanaan pendataan kemiskinan untuk Basis Data Terpadu. Tetapi pada kenyataannya peran BPS tidak begitu terlihat pada program PKH di kabupaten Bungo karena Dinas Sosial tidak langsung berkoordinasi dengan BPS. Seharunya lebih baiknya Dinas Sosial ada koordinasi langsung dari BPS karena jika data yang didapat langsung dari pusat walaupun sudah dilakukan pendataan awal dari BPS bisa saja data yang didapat belum tepat sasaran.

Selain Koordinasi pada program bantuan PKH ini ada yang juga penting dalam menunjang berhasinya kebijakan program ini yaitu dengan sosialisasi. Sosialisasi ada salah satu cara untuk menambah pengetahuan tentang PKH. Sosialisasi ini dilakukan oleh para UPPKH, sosialisasi dilaksanakan untuk memberikan pengarahan atau menambah pengetahuan penerima bahwa $\mathrm{PKH}$ adalah program bantuan yang diberikan untuk pendidikan dan kesehatan. Sosialisasi dilaksanakan juga agar penerima tidak salah guna uang bantuan. Pada program ini sosialisasi sudah dilaksanakan tetapi belum merata, sosialisasi yang rutin dilakukan hanya sosialisasi pertemuan perbulan yang dilakukan oleh Implementasi Program Keluarga 61 
pendamping dan penerima setiap satu bulan sekali. Sedangkan sosialisasi kepada semua penerima yang dilakukan oleh UPPKH belum dilakukan secara merata.

\section{Lingkungan Ekonomi, Sosial dan Politik}

Implementasi Kebijakan Publik dalam perspektif yang ditawarkan oleh Van Meter dan Van Horn adalah sejauhmana lingkungan eksternal turut mendorong keberhasilan kebijakan publik yang telah ditetapkan. Lingkungan sosial, ekonomi dan politik yang kurang kondusif dapat menjadi penyebab dari kegagalan kinerja implementasi kebijakan. Pada pelaksanaan Program Keluarga Harapan di kabupaten Bungo diketahui bahwa masih ada masyarakat yang belum mendapatkan bantuan $\mathrm{PKH}$, hal ini mengakibatkan adanya penolakan dan keluhan dari Perangkat Desa maupun masyarakat setempat. Mereka beranggapan sebenarnya layak untuk mendapatkan dana dari $\mathrm{PKH}$, tetapi pada kenyataannya tidak dapat bantuan. Begitupun dari pengamatan peneliti masih banyak masyarakat yang dikatakan memenuhi syarat untuk menjadi peserta $\mathrm{PKH}$ tapi tidak terdaftar menjadi peserta PKH. Dengan terjadinya kesenjangan dalam pemberian bantuan $\mathrm{PKH}$ ini membuat masyarakat yang tidak terdaftar dalam peserta $\mathrm{PKH}$ meminta kepada pendamping secara pribadi maupun kelompok untuk di daftarkan menjadi anggota. Mereka meminta secara pribadi kerumah pendamping agar bagaimanapun caranya untuk dimasukkan sebagai peserta. Namun dalam implementasinya ditemukan bahwa walaupun banyak masyarakat yang bukan peserta PKH memohon untuk didaftarkan sebagai peserta $\mathrm{PKH}$, tetapi pendamping tidak mempunyai wewenang untuk mengganti data peserta $\mathrm{PKH}$ yang di dapat dari kementerian sosial, mereka bisa mengurangi data yang terdaftar tetapi tidak bisa menambah ataupun mengganti peserta PKH. Pendamping bisa mengajukan ke Dinas Sosial untuk memasukan keluarga tersebut tetapi bukan untuk bantuan PKH melainkan bantuan lainnya seperti KIP, KIS dan sebagainya tetapi belum tentu namanya akan keluar setelah diproses.

Dalam menetukan kriteria miskin saat mengecek data yang diturunkan oleh Kementerian Sosial para pendamping PKH tidak hanya melihat dari rumah, tetapi juga melihat apakah calon peserta ini tidak mempunyai aset seperti kebun, uang tabungan dan lain sebagainya. Untuk di Kabupaten Bungo pendamping PKH bisa menerima calon peserta PKH menjadi peserta PKH jika suatu keluarga itu mempunyai komponen dan mempunyai enam dari empat belas kategori miskin. Dari pengamatan peneliti dilihat dari indikator keluarga sejahtera menurut BKKBN seharusnya yang mendapatkan atau yang menjadi peserta Program Keluarga Harapan ini adalah yang termasuk kedalam keluarga pra sejahtera, tetapi pada kenyataannya penerima PKH di Kabupaten Bungo ini termasuk Keluarga Sejahtera II yang mempunyai salah satu poin dari Keluarga Sejahtera II yaitu luas lantai setiap penghuni rumah 8 $\mathrm{m}^{2}$. Maka dapat disimpulkan bahwa ada kesenjangan dalam penentuan peserta penerima dana bantuan dari PKH sehingga menimbulkan gejolak dalam masyarakat yang akhirnya berdampak pada lingkungan ekonomi, sosial dan politik yang kurang kondusif.

\section{SIMPULAN}

Pada Implementasi Kebijakan PKH ini peneliti menggunakan model implementasi kebijakan Van Meter dan Van Horn yaitu : Ukuran standard dan kebijakan yang dimana dapat disimpulkan bahwa program bantuan ini bisa dikatakan berhasil tetapi untuk tujuan kebijakan belum $100 \%$ berhasil karena belum sepenuhmya bisa mencukupi kebutuhan pendidikan dan kesehatan; sumberdaya yang dalam hal ini ialah implementor program PKH dikabupaten Bungo sudah cukup baik secara kuantitas maupun kualitas; karakteristik agen pelaksana pada fakta dilapangan pendamping belum sepenuhnya memberikan ketegasan kepada penerima seperti sanksi yang berlaku; komunikasi antar organisasi aktivitas pelaksana pada $\mathrm{PKH}$ fakta dilapangan masih ada penerima yang belum mengetahui apa itu $\mathrm{PKH}$, ini membuktikan bahwa sosialisasi yang dilakukan kurang merata; Lingkungan ekonomi, sosial, politik pada fakta dilapangan masih ada penerima PKH di Kabupaten Bungo yang termasuk keluarga sejahtera II mendapatkan dana bantuan pada kenyataannya yang seharusnya mendapatkan batuan yaitu yang memenuhi kriteria bantuan adalah keluarga prasejahtera. Jika dilihat dari beberapa indikator yang belum terlaksana dengan baik maka dapat disimpulkan bahwa pada pelaksanaan program keluarga harapan dikabupaten bungo belum sepenuhnya dapat mewujudkan pemerataan kesejahteraan bagi masyarakat, hal ini ditunjukkan dari pembagian dana yang belum merata dan adanya ketidakadilan dalam penentuan peserta penerima dana $\mathrm{PKH}$, sehingga bagi masyarakat yang seharusnya memenuhi kriteria sebagai peserta justru tidak dapat membantu mereka baik dalam hal pendidikan maupun kesehatan.

\section{DAFTAR PUSTAKA}

Budi Winarno, Kebijakan Publik Teori \& Proses, PT. Buku Kita, Jakarta, 2008.

Direktorat Jendral Anggaran Kementrian Keuangan, Buku Panduan PKH, 2016.

Isbandi Rukminto Adi, Kesejahteraan Sosial, Raja Grafindo Persada, Jakarta, 2013.

Muahadam Labola, Memahami Ilmu Pemerintahan, Suatu Kajian, Teori, Konsep dan Penegembanganya, Raja Grafindo, Jakarta, 2007.

Mukhtar, Metode Praktis Penelitian Deskriptif Kualitatif, GP Press Group, Jakarta, 2013.

Poerwadarminata, Ilmu Sosial Dasar, Balai Pustaka, Jakarta, 2014.

Riant Nugroho, Kebijakan Publik "Formulasi, Implementasi, dan Evaluasi”, Gramedia, Jakarta, 2003.

Sri Masita Laluhang, Jurnal, Implementasi Program Keluarga Harapan (PKH) dalam Rangka Penanggulangan Kemiskinan Di Desa Kendahe II Kecamatan Kendahe Kabupaten Sangihe.

Sugiyono, Metode Penelitian Administrasi, Alfabeta, Bandung, 2012.

Suharsimi Arikunto, Prosedur Penelitian Suatu Pendekatan Praktik, Rineka Cipta. Jakarta, 1998.

Zulkarnain Umar, Jurnal, Analisis Implementasi Kebijakan Standar Pelayanan Minimal untuk peningkatan kualitas layanan publik, Universitas Islam Makasar, Makasar. 